\title{
Research on the Progress and Future Development of Technological Innovation of Intelligent Agricultural Machinery in China
}

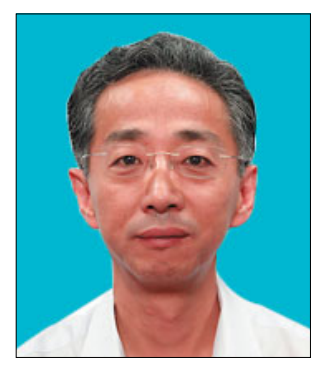

\section{Fang Xianfa,}

Ph.D., professor, e-mail: fangxf@caams.org.cn;
Wu Haihua,

Ph.D., professor, e-mail: caamswhh@163.com

Chinese Academy of Agricultural Mechanization Sciences, Beijing, People's Republic of China

Abstract. Agricultural machinery is the key field in modern scientific and technological innovation. In recent years, China has made great achievements in the development of high-performance intelligent agricultural machinery with cutting-edge technology, which promotes the efficient use of agricultural resources and environment-friendly development, and supports 70 percent of China's agricultural mechanization production. This paper mainly focus on the innovation and progress in the field of intelligent agricultural equipment technology in China from the aspects of information perception and precision production monitoring technology, intelligent operation management technologies, power machinery, farmland operation machinery, intelligent harvesting technology, production technology and agricultural products processing equipment. the paper also summarizes that, in the future, green, intelligence and universality will become the main characteristics of the development of intelligent agricultural machinery technology, and cross integration, extension and expansion will become the main direction of technological innovation. At last by referring to the application basis and cutting-edge technology of China's intelligent agricultural machinery industry, the innovation and development goals and research direction of future intelligent agricultural equipment, the scientific and technological innovation and industrial development trend in the field of agricultural mechanization and intelligent application integration, this paper puts forward some suggestions on the research direction of future intelligent agricultural equipment.

Keywords: agricultural machinery; innovation progress; development focus.

For citation: Xianfa F., Haihua W. Research on the progress and future development of technological innovation of intelligent agricultural machinery in China. Sel'skokhozyaystvennye mashiny i tekhnologii. 2021. Vol. 15. N4. 29-34 (In English). DOI 10.22314/2073-7599-2021-15-4-29-34.

\section{Исследование достижений и перспектив развития технологических инновацийв области интеллектуальной сельскохозяйственной техники в Китае}

\section{Фан Сяньфа,}

кандидат наук, профессор, e-mail: fangxf@caams.org.cn;

\author{
Ву Хайхуа, \\ кандидат наук, профессор, \\ e-mail: caamswhh@163.com
}

Китайская академия наук механизации сельского хозяйства, Пекин, Китайская Народная Республика

Реферат. Сельскохозяйственная техника стала ключевой областью современных научных и технологических инноваций. В последние годы Китай добился больших успехов в разработке высокопроизводительной интеллектуальной сельскохозяйственной техники и применении передовых технологий, которые способствуют эффективному использованию сельскохозяйственных ресурсов и экологически безопасному развитию, а также обеспечивают 70 процентов производства в области механизации сельского хозяйства в Китае. В этой работе основное внимание уделяется инновациям и достижениям в области технологии интеллектуального сельскохозяйственного оборудования в Китае, а именно вопросам восприятия информации, технологии точного мониторинга производства, проблемам технологий интеллектуального управления операциями, энергетического оборудования, машин для обработки сельскохозяйственных угодий, интеллектуальной тех- 
нологии сбора урожая, технологий производства и оборудования для переработки сельхозпродукции. В статье также прогнозируется, что в будущем экологичность, интеллект и универсальность станут основными характеристиками развития технологий интеллектуальной сельскохозяйственной техники, а перекрестная интеграция, рост и расширение неотрывно связаны с технологическими инновациями. Наконец, на основе прикладного характера китайской интеллектуальной сельскохозяйственной техники и передовых технологий, учитывая цели инновационного развития и направления исследований будущего интеллектуального сельскохозяйственного оборудования, принимая во внимание научные и технологические инновации и тенденции промышленного развития в области механизации сельского хозяйства и возможности интеллектуальной интеграции, авторы выдвигают некоторые предложения в направлении исследований будущего интеллектуального сельскохозяйственного оборудования.

Ключевые слова: сельскохозяйственная техника, инновационный прогресс, фокус развития.

ДДля цитирования: Синьфа Ф., Хайхуа В. Исследование достижений и перспектив развития технологических инноваций в области интеллектуальной сельскохозяйственной техники в Китае // Сельскохозяйственные махины и технологии. 2021. Т. 15. N4. C. 29-34 (In English). DOI 10.22314/2073-7599-2021-15-4-29-34.

A gricultural machinery is the key field in modern scientific and technological innovation. Since 2016, China has made significant achievements in technological studies, such as information perception in agricultural machinery operation, lean production, intelligent operation management; key equipment research, such as intelligent agricultural power machinery, efficient, precision and environmentally protective multi-functional field operation equipment, efficient and intelligent harvesting equipment for grain and cash crops, intelligent facility and lean production equipment, intelligent desiccation and precise grading equipment, as well as livestock and poultry processing equipment at the places of production, mechanized technology equipment in hilly and mountainous areas and paddy field. In developing high-performance intelligent agricultural machinery with cutting-edge science and technology, China has developed agricultural machinery that is applicable in featured areas and crops and animal husbandry, also developed small-scale agricultural machinery that finishes the whole production chain of tillage, seeding, planting, pesticide application, harvesting, storage and processing, and has realized whole process monitoring and regulation over production environment, process and operation quality, and has enhanced the application level of water, fertilizer and medicine and agricultural production capacity and efficiency, promoted efficient application of agricultural resources and environmental friendly development, and supported $70 \%$ of mechanized agricultural production in China [1].

Information perception and precision production monitoring technology in agricultural machinery operation

Focusing on agricultural lean production, China has developed soil environmental information such as soil moisture, temperature, water potential, tillage resistance, as well as sowing amount, fertilization amount, rice and wheat growth, crop yield and sensors for lean production information, and formed a lean production regulation system based on crop production process and realized the controlling and regulation of more than $70 \%$ key param- eters. China has developed a new mechanism for bio-mimetic farming and precision seeding based on information sensor control, raising the efficiency by about $10 \%$; it has developed physiological and ecological monitoring for livestock and poultry, and digital characterization and classification analysis, growth control and other technologies and sensor monitoring devices, and realized characterization and monitoring of more than 60 parameters, developed fine feeding devices and systems; studied the kinetic characteristics such as field work environment detection, track-slip rate and dynamic load, also realized operation status monitoring over seed flow, sowing and fertilizing depth, grain moisture, grain loss and other operational status, and its testing methods and technologies, and developed special sensing devices and systems, with detection errors of main parameters less than \pm 0.02 [2-3].

Intelligent operation and management technologies for agricultural machinery

Besides, China has developed positioning and navigation systems and devices based on Beidou system, self-organizing network technology, machine vision technology, host and machine coordination, path tracking and automatic obstacle avoidance under complicated working conditions with horizontal positioning accuracy of $1 \mathrm{~cm}$ $+1 \mathrm{ppm}$ and linear navigation accuracy less than $3 \mathrm{~cm}$ in high-speed operation; China has made breakthrough in multi-source information acquisition and fusion control of optoelectronics, electro-hydraulic, and developed intelligent variable application actuators and system devices for seeding, fertilization, irrigation, and pesticide application with response time based on multi-source information decision-making less than $5 \mathrm{~s}$, and variable control error less than 5\% FS; developed technologies and systems in intelligent control strategy, work flow detection, automatic fault diagnosis, cluster scheduling and remote operation and maintenance technology and system, which can meet the management requirements of agricultural machinery operation of more than 100,000 units; for smart farms, China developed operation decision-making and operation quality management technologies and systems 
and formed a typical intelligent control system for agricultural machinery, and realized the application of "Internet + agricultural machinery".

\section{Power machinery in intelligent farming}

Focusing on energy saving, emission reduction, and noise reduction, China has studied key technologies such as electrically controlled high-pressure injection for engine, exhaust gas recirculation, and exhaust gas after treatment, and developed systems for intelligent power output control, overall machine working status monitoring and fault diagnosis, and intelligent management systems. The small and large-scale agricultural diesel engine has been developed with maximum injection pressure of 2000 bar and a torque reserve of more than $30 \%$. China has developed technologies such as power shift and continuously variable transmission, electro-hydraulic lift and suspension type steering drive axle as well as intelligent control, also developed a series of heavy tractors with full power shift, continuously variable transmission, high and low power, which achieved more than 50 hours of trouble-free operation. China has also developed technologies of optimized power distribution and control, energy management strategy, double motor coupling, as well as key components in transmission, steering and suspension, and designed and developed 25 horsepower and 35 horsepower electric motors. China has developed chassis with high passability and high adaptability, gearbox combined with Hydrostatic Mechanical Transmission (HST/HMT) and mechanical transmission, light weight of the whole machine matched with working machine and intelligent control, developed tractors with suitable for hilly and mountainous areas and gradeability if more than $20^{\circ}$ and contour farming angle more than $15^{\circ}$; developed a 20 -horsepower four-wheel driven/wheel-track type, 70-horsepower crawler type, 80-horsepower crawler type paddy field tractors; developed 25-horsepower, 55-horsepower, and 80 -horsepower wheeled horticultural tractors, which provide green and efficient power for the diversified production of modern agriculture.

Efficient, accurate and environmentally friendly multifunctional farmland operation machinery

Aiming at the key links such as seeding, planting, weeding, fertilization and pesticide application, China has made breakthrough in some key technologies such as highspeed precision seeding metering, sowing depth control, and simultaneous seed fertilizer delivery, and developed high-speed precision seeding equipment for rice, soybeans, corn, and wheat and achieved over $90 \%$ of working precision at working velocity of $10 \mathrm{~km} / \mathrm{s}$; made breakthrough in seedling identification, high-speed seedling picking, precision planting, and developed equipment for high-speed super rice transplanting, rape and vegetable transplanting, with transplanting unit efficiency as high as 7200 seedlings/hour; developed technologies such as ground clearance/wheel gauge control, precision mixing of medicine liquid and seedling zone identification., de- veloped multi-functional field management equipment in high-clearance precision pesticide application and paddy field light plant protection, with the highest ground clearance height of $2 \mathrm{~m}$ and accuracy of liquid application control within $\pm 5 \%$; China has broken through the technology of airborne information detection, autonomous flight control, and pesticide application control, and developed a series of agricultural unmanned plant protection operation equipment, with cruise time over 30 minutes; studied soil rapid detection, protective tillage, soil residual film separation technologies, developed laser leveling, residual film separation, and subsurface pipe drainage for soil conditioning; developed technologies such as plot precision seeding, emasculation, pollination, high-cleanliness harvesting, and carried out integrated research and development of corn, wheat, rice, vegetable seed breeding and harvesting equipment [4-5].

Efficient and intelligent harvesting technology and equipment

China has made breakthrough in the key technologies of the combine harvester's intelligent working condition parameter control, high-efficiency and low-loss harvesting, high-throughput threshing and cleaning, and developed an intelligent and efficient rice-wheat combine harvester with a feed rate of over $10 \mathrm{~kg} / \mathrm{s}$. China has also made breakthrough in the key components such as corn plant cutting, low-loss ear picking, high moisture content kernel after low loss threshing, as well as intelligent control of working conditions based on loss rate, and developed corn grain harvester with single/double longitudinal axial flow, corn ear and stem harvesters, corn ear combine harvesters, fresh corn combine harvesters, and realized corn damage rate of less than $4 \%$ with a corn moisture content of about $30 \%$.

China has made breakthrough in technologies such as automatic alignment, online production measurement, and working condition monitoring, integrated intelligent control system for cotton picking, and developed a sixrow cotton box-type and packaged high-efficiency intelligent cotton picker. China has developed technologies such as efficient stalk cutting, low-loss transportation, and stalk-leaf separation, and integrated intelligent control technologies such as alignment and cutting depth, and developed a wheeled/track type sugarcane combine harvester, studied key technologies and devices for the intelligent and low-loss rape harvesting, and developed self-propelled rape combine harvester and rape swathing and picking harvester, reducing total loss rate by about $6 \%$; studied the technologies of drag reduction excavation, separation of fruit and soil, and high-efficiency fruit removal and cleaning, and developed high-efficiency self-propelled peanut combine harvesters and harvesters for digging and laying, picking and fruit removal, reducing total loss rate by about $4 \%$ [6-7].

Facility intelligent production technology and equipment 
Focusing on the lean production needs of vegetables, orchards, edible fungi, livestock and poultry, and aquatic products, taking environmental monitoring and control, efficient planting and harvesting, and intelligent management as the main tasks, China has developed:

- technologies such as standardized seedling cultivation for leaf vegetables, root vegetables, and solanaceous vegetables, seedbed finishing, precise seeding and highspeed planting;

- vegetable precise planting, high-speed planting, integrated water and fertilizer application, and combined harvesting equipment for carrots, cabbage, and brassica chinensis;

- deep fertilization, targeted variable plant protection, and grafting, bagging, harvesting, pruning and other equipment for lean production in orchards;

- high-efficiency and energy-saving facilities, fine environmental regulation, and nutrient coupling supply technologies, as well as intelligent equipment for light, temperature and humidity control, seedling cultivation and planting, seedbed space transport, and robot inspection and harvesting based on the growth characteristics of facility vegetables and edible fungi;

- equipment for precise control of the housing environment, personalized precise feeding, health identification and automatic milking, epidemic prevention and disinfection robots, and complete isolation and bio-safety disposal of sick and dead animals, and the intelligent control system for integrated animal and poultry breeding has realized large-scale application [8].

China has developed technologies such as water quality and environment online inspection and control, aquatic animal feeding behavior identification, and researched and developed intelligent precision feeding, mechanized low-loss fish classification, and the intelligent management and control system of facility aquaculture has been put into application.

Intelligent technical equipment for agricultural products processing

China has developed vibration cleaning, ultrasonic mixed flow cleaning, differential pressure pre-cooling, high-efficiency physical sterilization technologies on agricultural products, and developed low-loss cleaning and quality-preserving equipment for leafy vegetables, potatoes, camellia seeds, and walnuts. China has developed high-moisture multi-structure drying technology, quality-based drying coupling control, drying heat recovery and utilization, and developed high-efficiency and energy-saving drying equipment for seeds, fungi, and Chinese medicinal materials. Compared with traditional drying, the efficiency has been raised by more than $15 \%$, and the energy consumption has been reduced by over $30 \%$.

China has made breakthrough in real-time non-destructive testing of internal and external quality of fruits, such as high-throughput weight, sugar content, and appearance, and developed high-precision online weighing technologies, complete sets of automated grading equipment for citrus fruits and apples, with single-channel grading capabilities based on multi-source information over $300 /$ min, with accuracy greater than $95 \%$. China has developed short-flow cotton cleaning technology, foreign fiber detection based on spectral imaging, cotton moisture regain online monitoring, and developed intelligent moisture control, foreign fiber removal, new lint cleaning and ginning and other cotton upgrading intelligent equipment; developed the digital and intelligent control technology of tea fixation, flavoring, rolling, shaping and other processes based on quality evaluation, integrated the technology of removing and sorting out impurities, and developed a complete set of tea refining and processing equipment. The fresh leaf processing capacity is more than $400 \mathrm{~kg} / \mathrm{h}$.

China has also developed technologies such as synchronous sanitation inspection, multi-station efficient automatic peeling, automatic cleaning and disinfection of livestock carcasses, and precise and automatic online segmentation of poultry; developed a complete set of equipment for slaughter of cattle and sheep and poultry product segmentation. The automatic segmentation capacity of poultry is more than 6000 per hour. China has developed fish and shrimp identification, directional transportation, detection and classification technologies, and developed a complete set of equipment for automatic shrimp peeling and grading, and fish descaling and impurity removal. The processing efficiency of the shrimp peeling equipment reached $450 \mathrm{~kg} / \mathrm{h}$. China has developed technologies such as quality monitoring, multi-source information collection and control, environment regulation in storage and logistics distribution, and developed a quality control system for livestock, poultry and aquatic products for cold storage, refrigerated trucks, and refrigerated shelves, reducing the loss rate by more than $5 \%$.

\section{Situation and demand for future development}

Green, intelligence, and ubiquitousness have become the main characteristics of technological development. In recent years and for some time to come, the penetration and integration of artificial intelligence, big data, Internet of Things, 5G, and biotechnology is triggering a new round of technological changes in agricultural equipment. Agricultural equipment technology has moved from the mechanization stage where machinery replaces human and animal power to the automation stage based on electronic control technology, and enters a new stage of intelligence centered on information technology. It is developing in the direction of autonomous intelligence with artificial intelligence technology as the core, showing the trend of high efficiency, modernization, intelligence, networking and greening [9-10].

Cross integration, extension and expansion have become the main direction of technological innovation. The development of modern agricultural equipment and technology is facing the new situation and new opportunities 
in global agricultural transformation and the new challenges of global food security and climate change. It is necessary to promote multi-field and multi-industry collaborative innovation, continuously integrate biology, agronomy, and engineering technology, and highly integrate advanced manufacturing and information, new materials, new energy, to promote the systematization of soil-animals and plants-machines, the coordination of resources and the environment, the integration of agricultural machinery and agronomy, the joint development of equipment and information, to realize transformation of modern agriculture to precise control, equipment intelligence, lean production, green and efficient intelligent production.

The new generation of intelligent agricultural equipment industry is the main goal of technological development. Facing the new demands and new focus in transformation and upgrading of agricultural equipment industry, the rapid development of intelligent agriculture, and division and coordination of labor in international industries, technological innovation of China's agricultural equipment must be guided by the promotion of comprehensive agricultural mechanization and intelligent production and application, taking leading, supporting and cultivating emergent industry as the core task, China strives to promote the innovation of key core technologies in informatization and intelligentization and make up for the technical weaknesses in operation efficiency, loss control, water and fertilizer application control, and continuously strengthen the foundation, expand the field, extend the chain, improve the level, so as to improve the modernization of the industrial chain and build the new ecology for industrial development.

\section{Innovation goals}

Developing intelligent agricultural equipment is a strategic focus for China to realize rural revitalization, agricultural and rural modernization. China plans to make an overall planning of the innovation chain from application foundation to application demonstration, as well as the industrial chain of R\&D, design, manufacturing, and service, and the entire agricultural and rural chain of grain economics and feeding, planting, breeding and processing, production and ecological life, with integration between agricultural machinery and agronomy, equipment and information, manufacturing and services, and production and ecology as the main paths. Guided by such goals,

China will strengthen achievement orientation, promote international scientific and technological innovation cooperation, and develop a new generation of intelligent agricultural equipment technology and products, to make China's contribution to global agricultural development.

Research diREctions

1. Application foundation and cutting-edge technology. Focusing on the trends and needs of smart equipment, smart manufacturing, smart production and smart ser- vices, China aims to strengthen basic and cutting-edge technology research, such as fine control of individual animals and plants, structured environment construction of working conditions, sensing and control, autonomous and collaborative operations, robots and smart design applications, and explore the precise control mechanism of water, fertilizer, seed medicine and light, heat, and animal physiological behaviors and the environment, as well as the interaction mechanism of technological equipment, and the mechanism of human-computer-things integration in the operation process, and develop new mechanisms for cultivation and harvesting, new materials and agricultural sensors, high-efficiency drives, transmission and other key components, research and development environment and animal and plant growth inspection, process management, product collection and other operating robots, to form mechanized and intelligent technology system suitable for production scale and mode with the functions of information perception, quantitative decision-making, intelligent production and precise investment [10].

2. Technology research and development for major equipment. Focusing on improving efficient, intelligent and green agricultural equipment, China aims to develop multi-functional land preparation and efficient precision planting, fertilization, seeding, pesticide application, irrigation, and efficient harvesting of seeds and straws, as well as precision planting and efficient harvesting of vegetables and Chinese medicinal materials, large-scale harvesting of oilseeds, cotton, hemp, rubber, sugar cane, large-scale characteristic forest fruit tea, mulberry shaping and pruning, fertilization and pesticide application, fine harvesting and other efficient and intelligent operation equipment for grain and economic crops; develop intelligent heavy tractors and intelligent diesel-electric hybrid, unmanned driving, electric and new energy agricultural power vehicles; study and develop three-dimensional multi-layer high-efficiency facilities, factory-based intelligent planting and breeding equipment and facilities in environmental and energy efficiency control, lean production operations and management; study and develop high-efficiency breeding production equipment in precision breeding and seed expansion, fine selection and automatic seedling breeding; develop intelligent grassland animal husbandry production equipment for grassland conservation and forage and seed planting, harvesting and high-quality processing; develop equipment for soil quality improvement and farmland transformation, agricultural and rural ecological environment restoration and management, disaster prevention and mitigation, efficient storage and transportation of agricultural materials, and emergency production; develop intelligent equipment for the storage and transportation of agricultural, forestry, livestock and aquatic products, such as cleaning and grading, disinfection and sterilization, storage and transportation, and quality inspection, to form an independent and 
controllable new generation of intelligent agricultural equipment technology and product system, build the core competitiveness of the industry, and support the transformation and upgrading of the industry to mid-to-high end.

3. Agricultural mechanization and intelligent application integration. Focusing on the demands of modern agriculture for high-quality, high-efficiency, green ecology and sustainable development, China will study the efficient, standardized, and green production technology, supporting facilities and systematic modes under characteristics of different agricultural production areas, agronomic requirements, planting and breeding scales, farming systems and climate environment, and the efficient mechanized production technologies under the new seed breeding conditions and form an overall solution for planting, breeding, and production mechanization and intelligentization suitable for different scales, and carry out integrated research and development of operation equipment in hilly and mountainous areas, drying and storage mechanization equipment, and mechanized breeding equipment, mechanized equipment for agricultural and rural waste disposal and comprehensive utilization; carry out integrated research and development of equipment for laser leveling, precision seeding, precise pesticide application, high-efficiency fertilization, integrated water and fertilizer, water-saving irrigation, high-efficiency and low-loss harvesting, carry out integrated research and development of equipment for agricultural intelligent, unmanned production and processing equipment application, promote the high-quality, efficient, green and sustainable development of modern agriculture.

Conclusions. Scientific and technological innovation is the key to achieving a higher level of development in agriculture. At present and in the years to come, we will witness continuous breakthroughs in gene editing, big data, artificial intelligence and extensive integration with various fields, which will trigger a new round of agricultural production methods, operation modes and industrial changes. Agricultural equipment is facing huge opportunities and challenges. It is necessary to pay more attention to the collaborative promotion of innovation from a global scale, with major equipment as the core, informationization and intelligence as the main line, to promote the integration of the Internet, Internet of Things, cloud computing, big data and agricultural machinery equipment and achieve the complementarity of traditional intensive farming and modern equipment, promote the transformation of agricultural development mode, constantly improve labor productivity, land output rate, resource utilization rate and comprehensive production capacity, and better guarantee global food supply.

\section{REFERENCES}

1. Deng X.M., Hu X.L., Bai Y.C., et al. National Agricultural Machinery Industry Innovation and Development Report (2018). Machinery Industry Press. 2019. 181-182.

2. Wu W J. Research on agricultural intelligent technology in mechanical engineering automation. Metallurgical Collections. 2020. Vol. 5. N3. 267-268.

3. Li L.L., Meng C.Y., et al. Application Research on information perception technology of tractor suspension system in field operation. Value Engineering. 2019. Vol. 38. N8. 167-169.

4. Ren N., Zhou J.N., Dai H.J., et al. Bibliometric analysis of information perception and precision agriculture research at home and abroad. Information exploration. 2017. Vol. 11. 104-113.

5. Sun H., Li S,. Li M.Z., et al. Research Progress on Application of agricultural information imaging perception and deep learning. Transactions of The Chinese Society of Agricultural Machinery. 2020. Vol. 51. N5. 1-17.

6. Liu P.Z., Meng X.W., et al. Design of precision agriculture information perception system based on Internet of things. Computer Engineering and Science. 2012. Vol. 34. N3. 137-141.

7. Sun S.P., Wei J.L., Hua C.Y. Application of intelligent technology in agricultural machinery. South Agricultural Machinery. 2020. Vol. 51. N20. 23, 25.

8. Wang B., Fang X.F., Wu H.H. Review and prospects of scientific and technological innovation of agricultural equipment in New China. Agricultural Machinery Quality and Supervision. 2019. Vol. 10. 12-14.

9. Liu C.L., Lin H.Z., Li Y.M., et al. Research status and development trend of intelligent control technology for agricultural equipment. Transactions of The Chinese Society of Agricultural Machinery. 2020. Vol. 51. N1. 1-18.

10. Ma H.T., Zhao X.Y., Tong Y.F. Intelligent agricultural equipment information system for intelligent manufacturing. Journal of Chinese Agricultural Mechanization. 2020. Vol. 41. N11. 171-177.

\section{Conflict of interest.}

The authors declare no conflict of interest.

All authors have read and approved the final manuscript.

Статья поступила в редакцию Статья принята к публикации
The paper was submitted to the Editorial Office on The paper was accepted for publication on
10.03.2021

25.05.2021 